Reprod. Nutr. Dévelop., 1986, 26 (3), 791-800.

\title{
Maternal testosterone and sexual differentiation of the male guinea-pig foetus
}

\author{
Nicole RIGAUDIĖRE, G. DESPRÉS
}

with the technical assistance of Aline VOLDOIRE and Danièle EPISSE

Laboratoire de Physiologie Animale et U.A. C.N.R.S. 1123,

Université de Clermont-Ferrand II, B.P. 45,

63170 Aubière, France.

Summary. The part of foetal testosterone originating from the mother was explored in the guinea-pig at the time of sexual duct differentiation on day 32 of gestation. Using constant intravenous infusion of tritiated testosterone in the maternal compartment, total radioactivity (RA) and radioactive testosterone $\left(\left|{ }^{3} \mathrm{H}\right| \mathrm{T}\right)$ and dihydrotestosterone (| ${ }^{3} \mathrm{H}$ | DHT) were measured in the maternal plasma, whole foetus and various foetal tissues, including the genital tract and gonads, brain and liver. After $\left|{ }^{3} \mathrm{H}\right| \mathrm{T}$ was infused to the mother, significant amounts of total RA were found in foetuses of both sexes. The two metabolites isolated from the whole foetus contributed in various amounts to the RA present : $8 \%$ for $\left|{ }^{3} \mathrm{H}\right| \mathrm{DHT}$ and 2 to $3 \%$ for $\left|{ }^{3} \mathrm{H}\right| \mathrm{T}$; no significant differences in the amounts of foetal $T$ derived from maternal $T$ (around $5 \mathrm{pg} / \mathrm{g}$ ) were found between male and female foetuses. The brain, liver and genital tract and gonads concentrated more RA than the whole foeius, but only the male genital tract and gonads concentrated more RA than maternal plasma. Only DHT was isolated from the brain and liver of both sexes 18 to $10 \%$ of the RA found), but neither of the two hormones was found in the genital tract and gonads of either male or females foetuses. The results indicated that maternal testosterone and its metabolite, DHT, were not directly involved in the differentiation of sexual ducts in the male guinea-pig foetus.

\section{Introduction.}

At the time of sexual differentiation in the male guinea-pig, the concentration of two androgens, testosterone (T) and dihydrotestosterone (DHT) (17 $\beta$-hydroxy$5 \alpha$-androstan-3-one), increases simultaneously in the maternal plasma (Rigaudière, Pradier and Delost, 1980) and in the male foetal gonads, plasma and Wolffian ducts (Rigaudière, 1979 ; Buhl, Pasztor and Resko, 1979 ; Vreeburg et al., 1981). A number of previous works in various mammals, including the guinea-pig and reviewed in Price et al. (1975), gave evidence that both T and DHT are the active androgens in Wolffian duct stabilization and differentiation. There is considerable evidence pointing to the foetal testis as the most important site of foetal $T$ and DHT synthesis (Brinkmann, 1977 ; Sholl and Goy, 1978 ; Rigaudière, 1979). 
In order to ascertain whether the male foetus alone is responsible for the differentiation of its own sexual ducts, certain problems must be investigated and, in particular, the possible contribution of maternal androgens to the masculinization of male offspring.

The present experiment, using a continuous infusion method, was designed to verify whether guinea-pig maternal testosterone participates in the androgenization of the male foetal ducts. Because of its potent action on male sexual differentiation, DHT, the $5 \alpha$-reduced metabolite of testosterone, was also studied in mothers and foetuses after maternal infusion of radioactive testosterone; both male and female foetuses of the litter were studied. In addition to the gonads and genital tract (external and internal genitalia), two other tissues were analysed : the brain because it is also an androgen target organ and the liver because of its role in hormonal catabolism.

\section{Material and methods.}

Animals, anaesthesia, surgery and foetal tissue collection. - The female guinea-pigs (Dunkin-Hartley strain) used for this experiment were from our laboratory colony. Adult females were caged with males for $24 \mathrm{~h}$ during oestrus (vaginal opening). The length of pregnancy was $68 \pm 1$ days; the mating day was day zero. The transfer of $T$ from mother to offspring was determined using constant intravenous infusion of tritium-labelled T. Surgery and tracer infusion were performed on a group of 10 pregnant females on day $32 \pm 1$ of gestation, when the sexual ducts in the male foetuses were differentiating.

Anaesthesia was induced with an i.p. injection of $35 \mathrm{mg}$ of sodium pentobarbitone $/ \mathrm{kg}$ of body weight. Polyethylene catheters (Biotrol Pharma, Paris) were inserted into the left carotid and right jugular vein. $T$ was continuously infused via the jugular catheter, and the arterial catheter was used to collect the blood samples. At the end of infusion and after blood sampling, the foetuses, obtained by caesarian section, were rapidly removed after the umbilical cord was clamped. Eighteen male and female foetuses were frozen whole in liquid nitrogen. From the others (6 males and 6 females), various tissues, including the brain, liver and gonads with genital tract, were rapidly removed, weighed and frozen until analysis.

Because of the minute size of the foetuses (about $2 \mathrm{~g}$ ) at this stage of gestation, individual plasma samples were too small to precisely estimate the amount of radioactivity present in the foetus. Therefore, the radioactivity of only whole foetuses and the above-mentioned foetal tissues was analysed. Individual foetal tissues were homogenized in a Virtis $\mathbf{4 7}$ homogenizer. Fatty material was removed from whole foetuses and livers as follows. The tissues were homogenized in $70 \%$ (v/v) aqueous methanol $(15 \mathrm{ml})$. After centrifugation for $30 \mathrm{~min}$ at $3000 \times \mathrm{g}$, the supernatant fractions were collected, stored overnight at $-20^{\circ} \mathrm{C}$ and centrifuged again for $20 \mathrm{~min}$ at $5700 \times \mathrm{g}$ to allow the fatty material to settle. The supernatant fractions were dried under nitrogen, redissolved in $3 \mathrm{ml}$ of aqueous methanol $(70 \% ; \mathrm{v} / \mathrm{v})$ and treated once more in the same manner. The dry resi- 
dues were dissolved in $3 \mathrm{ml}$ of water and extracted using a technique similar to that used for the other tissues and plasma samples (see below).

Tracer infusion and collection of blood samples. - 1, 2, 6, 7, 16, 17- ${ }^{3} \mathrm{H} \mid-$ testosterone (135-180 Ci/mmol) was obtained from New England Nuclear (NEN Gmbh, D 6072 Dreieich, Postfach 1240). Chemical purity was obtained $24 \mathrm{~h}$ before use by silica gel thin-layer chromatography using a benzene/ethylacetate system $(2: 1, \mathrm{v} / \mathrm{v})$. The labelled steroid was dissolved in ethanol, then diluted (1 to 9$)$ in a sterile solution of sodium chloride $(0.9 \%)$ and infused at $20 \mu \mathrm{l} / \mathrm{min}$ (about $0.16 \mu \mathrm{Ci} / \mathrm{min}, 290 \mathrm{pg} / \mathrm{min}$ ) ; a constant rate of delivery was ensured by a Braun constant infusion pump. Steady-state concentrations of $\left|{ }^{3} \mathrm{H}\right| \mathrm{T}$ were obtained for this rate after $50-60 \mathrm{~min}$. Three blood samples $(0.6 \mathrm{ml})$ were collected at 80,90 and $100 \mathrm{~min}$. The exact tracer infusion rate was determined by timed collection of the infusate after the last samples were obtained. Before the start of infusion, one blood sample $(0.6 \mathrm{ml})$ was drawn for the determination of the endogenous $T$. Immediately after sampling, the blood was centrifuged for $10 \mathrm{~min}$ at $3000 \times \mathrm{g}$ and the plasma samples were frozen at $-25^{\circ} \mathrm{C}$. Analysis was performed within one month after the experiment.

Experimental design, chromatography and measurement of radioactive and endogenous androgens. - To estimate procedural loss, $2000 \mathrm{dpm}$ of ${ }^{3} \mathrm{H} \mid$ labelled T were added to plasma samples obtained from animals before infusion of radioactivity, and $2000 \mathrm{dpm}$ of $4-\left|{ }^{14} \mathrm{C}\right| \mathrm{T}(50-60 \mathrm{mCi} / \mathrm{mmol})$ (New England Nuclear) were added to the plasma samples obtained after radioactive infusion. Extraction and chromatographic procedures were the same for radioactive and endogenous androgens. Extraction was performed twice with $7 \mathrm{ml}$ of cyclohexane-ethylacetate $(50: 50, v / v)$. The organic extracts were dried under nitrogen, redissolved with $2.5 \mathrm{ml}$ of isooctane and transferred to chromatographic columns. Celite columns were previously saturated with propylene glycol and washed with $10 \mathrm{ml}$ of isooctane. T elution was carried out stepwise, using the method of Garnier, Cotta and Terqui (1978). After extraction and column chromatography, recovery was within the $80-90 \%$ range for endogenous and labelled hormones in plasma samples and tissues analysed without fat removal (brain, gonads and genital tract). Recovery after extraction, methanol delipidation and chromatography (whole foetus and liver) was around $55 \%$.

Endogenous $\mathrm{T}$ was measured by radioimmunoassay as described previously (Rigaudière, 1979).

${ }^{3} \mathrm{H} \mid \mathrm{T}$ and $\left|{ }^{3} \mathrm{H}\right| \mathrm{DHT}$ samples were counted using an automatic liquid scintillation spectranalyser (Packard Tri-Carb $300 \mathrm{C}$ ). Dual isotope settings gave an efficiency of $30 \%$ for ${ }^{3} \mathrm{H}$ in the ${ }^{3} \mathrm{H}$ region and of $73 \%$ for ${ }^{14} \mathrm{C}$ in the ${ }^{14} \mathrm{C}$ region. An adequate spectral separation of ${ }^{3} \mathrm{H}$ and ${ }^{14} \mathrm{C}$ for our measurements was achieved by setting the regions of both radionucleides so as to minimize the ${ }^{3} \mathrm{H}$ contribution from the ${ }^{14} \mathrm{C}$ region $(<5 \%)$ and ${ }^{14} \mathrm{C}$ contribution from the ${ }^{3} \mathrm{H}$ region $(<12 \%) .{ }^{14} \mathrm{C}$ and ${ }^{3} \mathrm{H}$ values were given by the counter in disintegrations/min (dpm) after allowing for these contributions. The counting time was calculated to give a standard deviation of less than $1 \%$ for high counts and of less than $5 \%$ for low counts. 
Total RA in the maternal plasma and foetal tissues was measured as follows. Plasma $(500 \mu \mathrm{l})$ was directly counted in $10 \mathrm{ml}$ of Instagel (Packard) ; brain, genital tract and gonad homogenates $(1 \mathrm{ml})$ were counted in $10 \mathrm{ml}$ of toluene scintillator after solubilization in $1 \mathrm{ml}$ of Soluene 350 (Packard) for $4 \mathrm{~h}$ at $50{ }^{\circ} \mathrm{C}$; liver and whole foetus homogenates $(1 \mathrm{ml})$ were counted in $10 \mathrm{ml}$ of toluene scintillator after solubilization in $2 \mathrm{ml}$ of Soluene 350 for $8 \mathrm{~h}$ at $50^{\circ} \mathrm{C}$ and decoloration by $0.2 \mathrm{ml}$ of isopropyl alcohol for $30 \mathrm{~min}$ and $0.2 \mathrm{ml}$ of hydrogen peroxide solution (35\%) for $30 \mathrm{~min}$.

Radiochemical purity of labelled testosterone and DHT isolated from plasma and tissue homogenates after continuous infusion. - Using the constant specific activity of the two isotopes, we carried out preliminary experiments on (1) one plasma pool from the infused pregnant females and (2) one tissue pool from the foetuses to investigate the radiochemical purity of labelled $\mathrm{T}$ and $\mathrm{DHT}$. It was found that the ratio ${ }^{3} \mathrm{H}:{ }^{14} \mathrm{C}$ of labelled $\mathrm{T}$ and $\mathrm{DHT}$ was constant throughout (1) celite column chromatography, (2) silica gel thin-layer chromatography and (3) paper chromatography. After paper chromatography, unlabelled T or DHT was added to the eluates and then recrystallized to constant specific activity in ethanol-water and methanol-water successively. The ratios ${ }^{3} \mathrm{H}:{ }^{14} \mathrm{C}$ for $\mathrm{T}$ and DHT obtained after recrystallization were not significantly different from those obtained after celite column chromatography. The radiochemical purity achieved after celite column chromatography was $95 \%$ for $T$ and DHT.

\section{Calculation of various parameters and expression of results.}

1) In order to reduce inter- and intra-group variances due to individual variations in the infusion rate, ${ }^{3} \mathrm{H} \mid \mathrm{T}$ and $\left|{ }^{3} \mathrm{H}\right| \mathrm{DHT}$ concentrations were corrected on the basis of a constant infusion rate of $350000 \mathrm{dpm} / \mathrm{min}$.

In addition, in order to define the foetal : maternal ratio of radioactive compounds, the radioactive concentrations of maternal plasma and of foetal tissues were all expressed as $\mathrm{dpm} / \mathrm{g}$.

2) The following parameters were determined :

- the ratio of foetal-maternal concentration of total radioactivity :

$$
\frac{R A_{F}}{R A_{M}}=\frac{R A \text { in foetuses or in foetal tissues }(\mathrm{dpm} / \mathrm{g})}{\text { maternal plasma } R A(\mathrm{dpm} / \mathrm{g})}
$$

- the ratio of foetal-maternal concentration of ${ }^{3} \mathrm{H} T$ :

$$
\frac{\left|{ }^{3} \mathrm{H}\right| \mathrm{T}_{F}}{\left|{ }^{3} \mathrm{H}\right| \mathrm{T}_{\mathrm{M}}}=\frac{{ }^{3} \mathrm{H} \mid \mathrm{T} \text { in foetuses or in foetal tissue }(\mathrm{dpm} / \mathrm{g})}{\text { maternal plasma }\left.\right|^{3} \mathrm{H} \mid \mathrm{T}(\mathrm{dpm} / \mathrm{g})}
$$

- the amount (as $\mathrm{pg} / \mathrm{g}$ ) of foetal $\mathrm{T}$ derived from maternal $\mathrm{T}$ :

$$
\frac{\left|{ }^{3} \mathrm{H}\right| \mathrm{T}_{F}}{\left|{ }^{3} \mathrm{H}\right| \mathrm{T}_{M}} \times \text { plasma maternal } \mathrm{T} \text { concentration }(\mathrm{pg} / \mathrm{g})
$$

3) Means \pm S.E.M. were given. Statistical significance was calculated using the Mann-Whitney test. Differences between means were considered significant when $P<0.05$. 


\section{Results.}

Maternal plasma concentrations of radioactive compounds (table 1). ${ }^{3} \mathrm{H} \mid \mathrm{T}$ and $\left|{ }^{3} \mathrm{H}\right| \mathrm{DHT}$ in maternal plasma represented $37 \%$ of the total amount of radioactivity present at steady state, with a major part of $\left|{ }^{3} \mathrm{H}\right| \mathrm{T}$ $(35.7 \%)$ and a minor part of ${ }^{3} \mathrm{H} \mid \mathrm{DHT}(1.7 \%)$.

\section{TABLE 1}

Plasma concentrations (dpm/g) of total radioactivity $\left(\mathrm{RA}_{\mathrm{M}}\right),\left|{ }^{3} \mathrm{H}\right| \mathrm{T}$ and $\left|{ }^{3} \mathrm{H}\right| \mathrm{DHT}$ at steady state in the pregnant guinea-pig after constant infusion of $\left|{ }^{3} \mathrm{H}\right|$ testosterone on day 32 of gestation

\begin{tabular}{lrc}
\hline $\begin{array}{c}\text { Radioactive (a) } \\
\text { compounds }\end{array}$ & $\mathrm{dpm} / \mathrm{g}$ & $\%$ of $\mathrm{RA}_{\mathrm{M}}$ \\
\hline $\mathrm{RA}_{\mathrm{M}}$ & $51300 \pm 8080$ & - \\
$\left.\right|^{3 \mathrm{H}} \mid \mathrm{T}$ & $18100 \pm 1450$ & $35.7 \pm 4.9$ \\
$\left|{ }^{3} \mathrm{H}\right|$ DHT & $1250 \pm 270$ & $1.7 \pm 0.1$ \\
\hline
\end{tabular}

Number of pregnant guinea-pigs studied $=10$

(a) Corrected on the basis of a constant infusion flow-rate of $350000 \mathrm{dpm} / \mathrm{min}$.

Whole foetus and tissue contents and concentrations of radioactive compounds. - Foetal total radioactivity $(\mathrm{dpm} / \mathrm{g}$ ) (table 2) was 3 times lower than total radioactivity measured in the maternal plasma. Male and female foetuses showed very low concentrations $\left(\mathrm{dpm} / \mathrm{g}\right.$ ) of $\left|{ }^{3} \mathrm{H}\right| \mathrm{T}$ and identical concentrations of ${ }^{3} \mathrm{H} \mid \mathrm{DHT}$, as compared with maternal plasma $(\mathrm{dpm} / \mathrm{g})$. There were no diffe-

\section{TABLE 2}

Foetal content (dpm/foetus) and concentrations $(\mathrm{dpm} / \mathrm{g})$ of total radioactivity (RA $\mathrm{F}_{\mathrm{F}},\left|{ }^{3} \mathrm{H}\right| \mathrm{T}$ and $\left|{ }^{3} \mathrm{H}\right| \mathrm{DHT}$ after constant infusion of $\left|{ }^{3} \mathrm{H}\right|$ testosterone to the mother on day 32 of gestation.

\begin{tabular}{|c|c|c|c|c|}
\hline $\begin{array}{l}\text { Radioactive (a) } \\
\text { compounds }\end{array}$ & $\begin{array}{l}\text { Foetal } \\
\text { sex }\end{array}$ & $\mathrm{dpm} /$ foetus & $\mathrm{dpm} / \mathrm{g}$ & $\% \mathrm{RA}_{\mathrm{F}}$ \\
\hline $\mathrm{RA}_{\mathrm{F}}$ & $\begin{array}{l}M(b) \\
F(b)\end{array}$ & $\begin{array}{l}39400 \pm 2740 \\
38000 \pm 2070\end{array}$ & $\begin{array}{l}16900 \pm 1160 \\
16500 \pm 1160\end{array}$ & \\
\hline$\left|{ }^{3} \mathrm{H}\right| \mathrm{T}$ & $\begin{array}{l}M \\
F\end{array}$ & $\begin{array}{rr}760 \pm & 60 \\
1090 \pm & 140\end{array}$ & $\begin{array}{ll}330 \pm & 30 \\
480 \pm & 70\end{array}$ & $\begin{array}{l}2.0 \pm 1.0 \\
2.9 \pm 0.3\end{array}$ \\
\hline$\left|{ }^{3} \mathrm{H}\right| \mathrm{DHT}$ & $\begin{array}{l}M \\
F\end{array}$ & $\begin{array}{l}3140 \pm 280 \\
2870 \pm 280\end{array}$ & $\begin{array}{l}1350 \pm \\
1250 \pm\end{array}$ & $\begin{array}{l}8.1 \pm 0.6 \\
7.5 \pm 0.4\end{array}$ \\
\hline
\end{tabular}

(a) Corrected on the basis of a constant infusion flow rate of $350000 \mathrm{dpm} / \mathrm{min}$.

(b) $\mathrm{M}$, male $(n=10) ; \mathrm{F}$, female $(n=8)$. 
rences between male and female foetuses with regard to $\left|{ }^{3} \mathrm{H}\right| \mathrm{T}$ and ${ }^{3} \mathrm{H} \mid \mathrm{DHT}$.

The presence of radioactivity in the three tissues studied is shown in table 3 ; concentrations $(\mathrm{dpm} / \mathrm{g})$ of total radioactivity, | ${ }^{3} \mathrm{H} \mid \mathrm{T}$ and $\mid{ }^{3} \mathrm{H}$ DHT were higher than those measured in the whole foetus or maternal plasma. A significant sex difference in favour of male foetuses was observed in radioactive concentrations of the genital tract and gonads. The latter tissues retained more radioactivity than the liver and brain $(P<0.001)$.

\section{TABLE 3}

Foetal tissue content and concentrations of total radioactivity $\left(\mathrm{RA}_{T}\right)$, $\left|{ }^{3} \mathrm{H}\right| \mathrm{T}$ and $\left.\right|^{3} \mathrm{H} \mid \mathrm{DHT}$ after constant infusion of ${ }^{3} \mathrm{H} \mid$ testosterone to the mother on day 32 of gestation.

\begin{tabular}{|c|c|c|c|c|c|}
\hline Tissue (a) & $\begin{array}{l}\text { Radioactive (b) } \\
\text { compounds }\end{array}$ & $\begin{array}{l}\text { Fetal } \\
\text { sex }\end{array}$ & $\mathrm{dpm} /$ organ & $\mathrm{dpm} / \mathrm{g}$ & $\% R A_{T}$ \\
\hline \multirow[t]{4}{*}{ Brain } & $\mathrm{RA}_{T}$ & $\begin{array}{c}M \\
F\end{array}$ & $\begin{array}{l}4080 \pm 320_{N S} \\
4200 \pm 310\end{array}$ & $\begin{array}{l}18200 \pm 1430 \mathrm{NS} \\
18700 \pm 1230\end{array}$ & - \\
\hline & $\left|{ }^{3} \mathrm{H}\right| \mathrm{T}$ & $M-F$ & 0 & 0 & 0 \\
\hline & $\left|{ }^{3} \mathrm{H}\right| \mathrm{DHT}$ & M & $320 \pm 60_{N S}$ & $1430 \pm 240_{\mathrm{NS}}$ & 8.2 \\
\hline & & $F$ & $330 \pm 40$ & $1450 \pm 170$ & 9.1 \\
\hline \multirow[t]{3}{*}{ Liver } & $\mathrm{RA}_{\mathrm{T}}$ & $\begin{array}{c}M \\
F\end{array}$ & $\begin{array}{l}3450 \pm 140_{N S} \\
2670 \pm 170\end{array}$ & $\begin{array}{l}30900 \pm 800 \mathrm{NS} \\
26200 \pm 2200\end{array}$ & $\begin{array}{l}- \\
-\end{array}$ \\
\hline & $\left|{ }^{3} \mathrm{H}\right| \mathrm{T}$ & $M-F$ & 0 & 0 & 0 \\
\hline & $\left|{ }^{3} \mathrm{H}\right| \mathrm{DHT}$ & $\begin{array}{c}\mathrm{M} \\
\mathrm{F}\end{array}$ & $\begin{array}{l}350 \pm 40_{\mathrm{NS}} \\
260 \pm 50\end{array}$ & $\begin{array}{l}3160 \pm 3^{350} \mathrm{NS} \\
2470 \pm 310\end{array}$ & $\begin{array}{r}10.2 \\
9.6\end{array}$ \\
\hline \multirow[t]{3}{*}{$\begin{array}{l}\text { Gonads }+ \\
\text { genital tract }\end{array}$} & $\mathrm{RA}_{\mathrm{T}}$ & $\begin{array}{l}M \\
F\end{array}$ & $\begin{array}{r}1140 \pm 190 \\
360 \pm 100^{*}\end{array}$ & $\begin{array}{l}61700 \pm 8890 \\
24500 \pm 6600^{* *}\end{array}$ & $\begin{array}{l}- \\
-\end{array}$ \\
\hline & $\left|{ }^{3} \mathrm{H}\right| \mathrm{T}$ & $M-F$ & 0 & 0 & 0 \\
\hline & $\left|{ }^{3} \mathrm{H}\right| \mathrm{DHT}$ & $M-F$ & 0 & 0 & 0 \\
\hline
\end{tabular}

(a) Number of tissue samples analysed : 6

(b) Corrected on the basis of a constant infusion flow rate of $350000 \mathrm{dpm} / \mathrm{min}$. Significance of the differences between male and female tissues: ${ }^{* *} P<0.01,{ }^{*} P<0.02$; NS, not significant.

As concerns the identified labelled hormones, | ${ }^{3} \mathrm{H} \mid \mathrm{DHT}$ was present in the liver and brain; the absence of $\left|{ }^{3} \mathrm{H}\right| \mathrm{T}$ and $\mathrm{DHT}$ in the gonads and tracts was particularly evident.

Foetal : maternal ratio of concentrations of ${ }^{3} \mathrm{H} \mid T$ and amounts of foetal $T$ derived from maternal $T$ in the whole foetus and foetal tissues. - The foetomaternal ratio observed (table 4) for the liver, genital tract and gonads was higher than that for the whole foetus and brain. A ratio of more than 1 for the male gonads and genital tract indicates that these tissues accumulated the radioactivity coming from maternal plasma. 
Maternal plasma endogenous testosterone measured using radioimmunoassay was $249 \pm 18 \mathrm{pg} / \mathrm{g}$. The amount of foetal $\mathrm{T}$ derived from maternal $\mathrm{T}$ was $4.8 \pm 0.2$ and $5.6 \pm 0.6 \mathrm{pg} / \mathrm{g}$ for male and female foetuses, respectively.

TABLE 4

Ratio of feetal/maternal concentrations of total radioactivity $\frac{R A_{1}}{R A_{M}}$ and of $\left|{ }^{3} \mathrm{H}\right| \mathrm{T} \frac{\left|{ }^{3} \mathrm{H}\right| \mathrm{T}_{\mathrm{F}}}{\left|{ }^{3} \mathrm{H}\right| \mathrm{T}_{M}}$ and amounts $(\mathrm{pg} / \mathrm{g}$ ) of fetal $\mathrm{T}$ derived from maternal $\mathrm{T}$ in the whole foetus and in foetal tissues

\begin{tabular}{|c|c|c|c|c|}
\hline Tissue $\left({ }^{a}\right)$ & $\begin{array}{l}\text { Fœtal } \\
\text { sex }\end{array}$ & $\frac{R A_{1}}{R A_{M}}$ & $\frac{\left|{ }^{3} \mathrm{H}\right| \mathrm{T}_{\mathrm{V}}}{\left|{ }^{3} \mathrm{H}\right| \mathrm{T}_{\mathrm{M}}}$ & $\frac{\left|{ }^{3} H\right| T_{F}}{\left|{ }^{3} H\right| T_{M}} \times C^{(1)} T_{M}\left({ }^{b}\right)$ \\
\hline Whole foetus & $\begin{array}{c}M \\
F\end{array}$ & $\begin{array}{l}0.38 \pm 0.06_{\mathrm{NS}} \\
0.40 \pm 0.04\end{array}$ & $\begin{array}{l}0.018 \pm 0.002_{\mathrm{NS}} \\
0.029 \pm 0.004\end{array}$ & $\begin{array}{l}4.8 \pm 0.2_{\mathrm{NS}} \\
5.6 \pm 0.6\end{array}$ \\
\hline Brain & $\begin{array}{c}M \\
F\end{array}$ & $\begin{array}{l}0.37 \pm 0.05_{\mathrm{NS}} \\
0.34 \pm 0.02\end{array}$ & $\begin{array}{l}0 \\
0\end{array}$ & $\begin{array}{l}0 \\
0\end{array}$ \\
\hline Liver & $\begin{array}{c}M \\
F\end{array}$ & $\begin{array}{l}0.60 \pm 0.10_{\mathrm{NS}} \\
0.48 \pm 0.06\end{array}$ & $\begin{array}{l}0 \\
0\end{array}$ & $\begin{array}{l}0 \\
0\end{array}$ \\
\hline $\begin{array}{l}\text { Gonads }+ \\
\text { genital tract }\end{array}$ & $\begin{array}{c}M \\
F\end{array}$ & $\begin{array}{l}1.08 \pm 0.29_{\mathrm{NS}} \\
0.48 \pm 0.15\end{array}$ & $\begin{array}{l}0 \\
0\end{array}$ & $\begin{array}{l}0 \\
0\end{array}$ \\
\hline
\end{tabular}

(a) Number of tissue samples: 6

(b) Endogenous plasma testosterone concentration in mother was found to be $249 \pm 18 \mathrm{pg} / \mathrm{g}$ $(n=10)$ in this experiment. Significance of the differences betweeen sexes: NS, not significant.

\section{Discussion.}

The amount of $\left|{ }^{3} \mathrm{H}\right| \mathrm{T}(290 \mathrm{pg} / \mathrm{min})$ infused in pregnant females was considered as physiological when compared to the production rate of endogenous $\mathrm{T}$, evaluated at $4920 \mathrm{pg} / \mathrm{min}$ in the guinea-pig at this stage of gestation (Després, Rigaudière and Delost, 1982). Moreover, infusion increased the maternal endogenous concentration of $T$ by only $5 \%(14 \mathrm{pg})$. The results of the experiment under these physiological conditions imply the transfer of considerable radioactivity from mother to offspring. However, it appears that $T$ and DHT, which contributed to $37 \%$ of the total radioactivity in maternal plasma at steady state, represented no more than $10 \%$ of the radioactivity present in the whole foetus. On the other hand, only DHT subsisted and contributed to $10 \%$ of the total radioactivity in the brain and liver, whilst neither of the hormones was present in the genital tissues. These results are in accordance with the findings of Vreeburg et al. (1981) obtained in guinea-pigs at later stages of gestation and with different conditions of infusion; these authors demonstrated that $\mathrm{T}$ could hardly penetrate into the foetus from the mother's circulation.

Several factors may be involved in the prevention of $T$ transfer : the retention of $\mathrm{T}$ and $\mathrm{DHT}$ in the maternal compartment by progesterone-binding globulin 
(PBG) which has a high affinity for these two steroids (Milgrom et al., 1973; Rigaudière et al., 1980 ; Heap, Ackland and Weir, 1981); placental catabolism due to a high activity of $5 \alpha$-steroid reductase and $3 \alpha, 3 \beta$ and $17 \beta$-hydroxysteroid dehydrogenase, resulting in the production of large amounts of androsterone when androstenedione, the precursor of $T$, is used as substrate for placental homogenates (Grossman and Bloch, 1983). Last of all, it is likely that the foetal liver served as a final barrier to the androgens since the major part of the placental blood passes through the liver before reaching the foetal peripheral circulation. The presence of a high content and concentration of radioactivity in the liver favours the argument that androgens are extracted from foetal blood by the liver.

Two results of the present work are of particular interest. At the time of differentiation, the genital tract and gonad tissue sequestered more radioactivity than any other tissues and seemed to be preferential target organs for $T$ metabolites. On the other hand, no trace of tritiated T and DHT was found in these genital structures. It has been reported that, under physiological conditions, testosterone is the active inducer of Wolffian duct differentiation in guinea-pigs (Wilson, 1971), rats (Wilson and Lasnitzki, 1971), rabbits (Wilson, 1973) and humans (Wilson and Siiteri, 1973), while the urogenital sinus and urogenital tubercle are dihydrotestosterone-dependent. In this case, the male guinea-pig foetus may be solely responsible for its sexual differentiation, due to foetal testicular androgens, since there is no maternal contribution to foetal T and DHT. The question arises whether T metabolites other than DHT could promote duct masculinization. Results in the literature indicate that $5 \alpha$-androstane-3 $\alpha, 17 \beta$-diol $(3 \alpha$-androstanediol) is more potent than $T$ and DHT in the induction of the epididymis, vas deferens and seminal vesicles in rat embryos, while $3 \alpha$-hydroxy- $5 \alpha$-androstan-17-one (androsterone) is completely ineffective (Schultz and Wilson, 1974). Androsterone was found to be the major metabolite in foetal tissues (body, brain and plasma) after constant ${ }^{3} \mathrm{H} \mid \mathrm{T}$ infusion in female guineapigs on day 36 of gestation, the amount of $3 \alpha$-androstanediol being 5 times lower (Vreeburg et al., 1981). If rats and guinea-pigs are comparable models for studying the effectiveness of androgens and their metabolism in foetal sexual tissues, then it is likely that testosterone metabolites make a marginal contribution to masculinization of the genital structures.

In brain structures, only DHT coming from maternal $\mathrm{T}$ was observed in guinea-pigs on day 32 of foetal life. It has been demonstrated that guinea-pig neural tissues convert T to DHT both in vitro (Sholl, Robinson and Goy, 1975) and in vivo (Sholl and Goy, 1981). This capacity, considered together with the behavioural effects of exogenous DHT when administered to guinea-pigs as soon as day 28 of foetal life (Alsum an Goy, 1974; Goldfoot and van der Werff Ten Bosch, 1975), suggests that DHT receptors might be present in the foetal brain and have a role in its sexual differentiation. 
Résumé. Testostérone maternelle et différenciation sexuelle du fœtus de Cobaye mâle.

La participation de la testostérone maternelle à la testostérone fœtale a été étudiée au moment de la différenciation des canaux sexuels chez le Cobaye (32 $\mathrm{j}$ de gestation). La testostérone tritiée $\left(\left|{ }^{3} \mathrm{H}\right| \mathrm{T}\right)$ et la dihydrotestostérone tritiée $\left(\left|{ }^{3} \mathrm{H}\right| \mathrm{DHT}\right)$, ainsi que la radioactivité totale (RA), ont été mesurées dans le plasma maternel, dans le fœtus entier et dans divers tissus fotaux, dont l'ensemble tractus génital et gonades, après perfusion continue de $\left|{ }^{3} \mathrm{H}\right| \mathrm{T}$ à la mère. Les résultats montrent qu'après perfusion continue de $\left|{ }^{3} \mathrm{H}\right| \mathrm{T}$ à la mère, la RA des fœtus est importante dans les deux sexes. La ${ }^{3} \mathrm{H} \mid \mathrm{DHT}$ et la $\left|{ }^{3} \mathrm{H}\right| \mathrm{T}$ représentent respectivement 8 et $3 \%$ de la radioactivité totale des fœetus entiers ; aucune différence dans la quantité de $T$ fœetale dérivée de la $T$ maternelle n'a pu être mise en évidence entre les deux sexes. Le cerveau, le foie et l'ensemble tractus génital et gonades concentrent plus de RA que le fœtus entier, mais seul l'ensemble tractus et gonades concentre plus de RA que le plasma maternel. La ${ }^{3} \mathrm{H} \mid \mathrm{DHT}$ a pu être isolée dans le cerveau et le foie des fœetus mâles et femelles ( 8 à $10 \%$ de la RA), mais aucune des deux hormones tritiées n'a été identifiée dans l'ensemble tractus et gonades des deux sexes. Les résultats indiquent que la testostérone maternelle et son métabolite, la DHT, ne sont pas directement impliqués dans la différenciation des canaux sexuels du fœetus mâle de Cobaye.

\section{References}

ALSUM P., GOY R. W., 1974. Actions of esters of testosterone, dihydrotestosterone or estradiol on sexual behavior in castrated male guinea-pigs. Hormones Behav., 5, 207-216.

BRINKMANN A. O., 1977. Testosterone synthesis in vitro by the fetal testis of guinea-pig. Steroids, 29, 861-873.

BUHL A. E., PASZTOR L. M. RESKO S. A., 1979. Sex steroids in guinea-pig fetuses after sexual differentiation of the gonads. Biol. Reprod., 21, 905-908.

DESPRÉS G., RIGAUDIĖRE N., DELOST P., 1982. Changes in metabolic clearance rate and plasma production rate of testosterone in the pregnant guinea-pig. Steroids, 39, 703710.

GARNIER D. H., COTTA Y., TERQUI M., 1978. Androgen radioimmunoassay in the ram : results of direct plasma testosterone and dehydroepiandrosterone measurements and physiological valuation. Ann. Biol. anim. Bioch. Biophys., 18, 265-281.

GOLDFOOT D. A., van der WERFF TEN BOSCH J. J., 1975. Mounting behavior of female guineapigs after prenatal and adult administration of the propionates of testosterone, dihydrotestosterone and androstanediol. Hormones Behav., 6, 139-148.

GROSSMAN B., BLOCH E., 1973. Comparative placental steroid synthesis. II. C-19 steroid metabolism by guinea-pig placentas and fetal adrenals in vitro. Steroids, 21, 813-832.

HEAP R. B., ACKLAND N., WEIR B. J., 1981. Progesterone-binding proteins in plasma of guineapigs and other hystricomorph rodents. J. Reprod. Fertil., 63, 477-489.

MILGROM E., ALLOUCH P., ATGER M., BAULIEU E. E., 1973. Progesterone binding plasma protein of pregnant guinea-pig. J. biol. Chem., 248, 1106-1114.

PRICE D., ZAAIJER J. J. P., ORTIZ E., BRINKMANN A. O., 1975. Current views on embryonic sex differentiation in reptiles, birds and mammals. Amer. Zool., 15, suppl. 1, 173-195.

RIGAUDIÉRE N., 1979. The androgens in the guinea-pig foetus throughout the embryonic development. Acta endocrinol., 92, 174-186. 
RIGAUDIÉRE N., PRADIER P., DELOST P., 1980. Free and bound androgens in the female guinea-pig during gestation and after parturition and in the offspring during the perinatal period. Acta endocrinol., 95, 101-109.

SCHULTZ F. M., WILSON J. D., 1974. Virilization of the Wolffian duct in the rat fetus by various androgens. Endocrinology, 4, 979-986.

SHOLL S. A., GOY R. W., 1978. Androgen and estrogen synthesis in the fetal guinea-pig gonad. Biol. Reprod., 18, 160-169.

SHOLL S. A., GOY R. W., 1981. Dynamics of testosterone, dihydrotestosterone and estradiol-17 uptake and metabolism in the brain of the male guinea-pig. Psychoneuroendocrinology, 6 , $105-111$.

SHOLL S. A., ROBINSON J. A., GOY R. W., 1975. Neural uptake and metabolism of testosterone and dihydrotestosterone in the guinea-pig. Steroids, 25, 203-215.

VREEBURG J. T., WOUTERSEN P. J. A., OOMS M. P., van der WERFF TEN BOSCH J. J., 1981. Androgens in the fetal guinea-pig after maternal infusion of radioactive testosterone. $J$. Endocr., 88, 9-16.

WILSON J. D., 1971. Testosterone metabolism in skin. Symposium der Deutschen Gesellschaft für Endokrinologie, 17, 11-18.

WILSON J. D., 1973. Testosterone uptake by the urogenital tract of the rabbit embryo. Endocrinology, 92, 1192-1199.

WILSON J. D., LASNITZKI I., 1971. Dihydrotestosterone formation in fetal tissues of the rabbit and rat. Endocrinology, 89, 659-668.

WILSON J. D., SIITERI P. K., 1973. The role of steroid hormones in sexual differentation. In SCOW R. O., Endocrinology, 1051-1056, Experta med. Amsterdam. 